\title{
Holders of the Keys: The Grand Chamberlain, the Grand Equerry and Monopolies of Access at the Early Modern French Court
}

Jonathan Spangler

There are a lot of doors in the world of the court, many of them shut. He who holds the keys controls access to the treasure within - in the case of the Chambre du Roi, the monarch himself. Entrusting a set of keys to someone involves-literally-trust. So whom did the King of France trust? Who was given authority to regulate proximity, the sine qua non for the acquisition of power and wealth? Perhaps these were the personal favourites of the monarch, men he had grown up with. Or perhaps they were men of exalted rank and ancient lineage, qualities which, as explained by Castiglione, would compel them to act in an upright manner so as not to sully family honour. ${ }^{1}$ Or even more narrowly, perhaps the sovereign would depend on princes of his own blood, whose sense of dynastic honour was tied up even more completely with his own.

Yet it would be foolish for any monarch to trust the strength of blood implicitly: numerous lessons can be learned from the continual rebellions of royal uncles in the fifteenth century to those of royal brothers and cousins in the seventeenth. ${ }^{2}$ Yet this is precisely what was attempted in the refining of the regulations of the French court from the reigns of Henri III to Louis XIV, as has been analysed by scholars from Richard Jackson to Katia Béguin. ${ }^{3}$ By providing the princes of the blood with a more permanent, secure function at court, the monarchy in a way disempowered them — by taking away their justification for rebellion — but also empowered them, to contribute to, rather than compete with, the overall power of the court and the dynasty. ${ }^{4}$

\footnotetext{
${ }^{1}$ Baldassare Castiglione, The Book of the Courtier, trans. Sir Thomas Hoby, (London: D. Nutt, 1900), Book I, 44.

${ }^{2}$ For a thorough study of the rationalisation of princely rebellion, see Caroline Bitche, Vie et carrière d'Henri II de Bourbon, prince de Condé (1588-1646). Exemple de comportement et d'idées politiques au début du XVIIe siècle (Paris: Champion, 2008), particularly the section “Autopsie d'une rebellion”, pp. 193-210.

${ }^{3}$ Richard A. Jackson, "Peers of France and Princes of the Blood", French Historical Studies, 7, 1 (1971), 27-46; Katia Béguin, "Louis XIV et l'aristocratie: coup de majesté ou retour à la tradition?", Histoire, économie et société, 19, 4 (2000), 497-512.

${ }^{4}$ For the most recent work on the interaction between the monarchy, the princes of the blood, and the court aristocracy more generally, see Nicolas Le Roux, Le Roi, la Cour, l'Etat. De la Renaissance à l'Absolutisme (Seyssel: Champ Vallon, 2013). Useful overviews of the evolution of the French court can be found in JeanFrançois Solnon, La Cour de France (Paris: Fayard, 1987); and Jeroen Duindam, Vienna and Versailles: the Courts of Europe's Major Dynastic Rivals, 1550-1780 (Cambridge: Cambridge University Press, 2003).
} 
The clearest example of this is the office of the Grand Master of France, held continuously by the younger branch of the House of Bourbon from 1594 to the fall of the monarchy. ${ }^{5}$ Although the position was highly prestigious, not to mention extremely lucrative in terms of sales of positions within his department, nevertheless, from the late sixteenth century onwards, the Grand Master did little in actually regulating the day-to-day running of the royal household. ${ }^{6}$ It was not, however, the Grand Master's job to regulate access the person of the monarch. This was initially the job of the courtier whose essence was symbolised by his heraldic device: the crossed keys. The Grand Chamberlain of France had the right to include these keys on his coat-of-arms, and indeed, his personal arms were traditionally depicted on the doorway of the king's bedchamber, a reminder of his authority in that space. ${ }^{7}$ So what men held this post? And to what degree did they actually exercise control of access? Did this level of control change across the early modern period?

Furthermore, the king of France was not always in his bedchamber. Other officers of the household therefore regulated access within the palace, notably the Captain of the Guard or the Grand Prévôt. And when the king went outside the palace, went riding, hunting, or to war, he was accompanied by the Grand Equerry of France. The French title, 'Grand Ecuyer' is sometimes translated as the 'Grand Squire' (the equivalent to the Master of the Horse in England), though his heraldic symbol was not, as one might expect horse related, but points instead to the access-regulating responsibilities of his office: the sword of state, kept in its sheath, but ready to be unsheathed to defend the monarch in public, especially during grand royal ceremonies. ${ }^{8}$ His importance within court society is underlined by the traditional name he was given by his contemporaries: simply 'Monsieur le Grand'. No other information was required. ${ }^{9}$ As with the Grand Chamberlain, we can ask similar questions about the men who held this post, and the degree of change across the Ancien Régime.

The overall question to be posed here is as follows: did the Bourbon monarchs trust the men who held the posts of Grand Chamberlain and Grand Equerry because they were

\footnotetext{
${ }^{5}$ This includes six Condés, two Soissons and a Conti. There is the exception of Prince Thomas of Savoy (an heir of Soissons) who held the post from 1654-56 while the Grand Condé was in exile.

${ }^{6}$ Christophe Blanquie, "Dans la main du Grand maître. Les offices de la maison du roi, 1643-1720", Histoire \& Mesure, 13, 3/4 (1998), 243-288.

${ }^{7}$ Père Anselme de Sainte-Marie (Pierre de Guibors), Histoire Généalogique et Chronologique de la Maison Royale de France, des Pairs, des Grands Officiers de la Couronne \& de la Maison du Roy, ... (9 vols., Paris, 1726-33), VIII, 437ff; Félix, comte de France d'Hézecques, Souvenirs d'un page de la cour de Louis XVI (Paris: Didier, 1873), 152.

${ }^{8}$ Anselme, Histoire Généalogique, VIII, 463ff.

${ }^{9}$ Daniel Reytier, "Un service de la Maison du roi: les écuries de Versailles (1682-1789)", in Les écuries royales du XVI $I^{e}$ a $X V I I I^{e}$ siècle, eds. Daniel Roche and Daniel Reytier(Paris: Association pour l'académie d'art équestre de Versailles, 1998), 61-95.
} 
personal favourites, or did he trust them because of their noble lineage and high rank? Or, as Roger Mettam has suggested, did a king such as Louis XIV in fact not trust his senior-most grandees at all, and kept them close to keep them out of mischief? ${ }^{10}$ This essay will examine how the dual factors of personal intimacy and familial rank of these two key office-holders, regulators of access, changed across the period, and how this change affected the health of the monarchy and the nobility as a whole. ${ }^{11}$ I will argue that both of these offices began as living symbols of royal trust and intimacy, but that they both were transformed in the sixteenth and seventeenth centuries into hereditary sinecures to support the grandeur and fiscal health of the great court families - not the monarchy. Historians have argued that any real control of access to the monarch was lost by this point, and that these offices became purely ceremonial. ${ }^{12} \mathrm{I}$ will conclude to the contrary that at least one of these Great Offices of the Crown, perhaps both, continued to control access to the court more generally, not just to the monarch, with impact on the provincial nobility across France, in a manner mostly unrecognised by historians of the court, namely through the recruitment of junior court officers such as royal pages, ushers and valets.

\section{Proximity and Intimacy}

The 'Great Offices of the Crown of France' were the heads of each of the main organs that assisted the monarch in the running of the French state (court, government, military), as they evolved from the nucleus of the medieval household. ${ }^{13}$ Of the two we are concerned with here, the office of Grand Chamberlain has a longer lineage than its counterpart in the stables,

\footnotetext{
${ }^{10}$ Roger Mettam, Power and Faction in Louis XIV's France (Oxford: Blackwell, 1988), 93. Mettam suggests that the Duc de la Rochefoucauld received the post of Grand Veneur (Master of the Hunt) from Louis XIV because it was a year-round post; he was thus required to attend the King at all times and therefore unable to make trouble in his governorship or his private estates in Poitou.

${ }^{11}$ This relates to the on-going debate about 'ossification' of the monarchy in its relationship with the nobility in the eighteenth century. See Bernard Hours, Louis XV et sa cour. Le roi, l'etiquette, et le courtesan (Paris: Presses universitaires de France, 2002); Leonhard Horowski, Die Belagerung des Thrones: Machtstrukturen und Karrieremechanismen am Hof von Frankreich 1661-1789 (Ostfildern: Jan Thorbecke Verlag, 2012); an early version of this work appeared in English as "Such a Great Advantage for My Son: Office-holding and career mechanisms at the Court of France, 1661-1789", in The Court Historian, 8 (2003), 125-175.

12 For example, Joseph-Nicolas Guyot, Traité des droits, fonctions, franchises, exemptions, prerogative et privileges annexes à chaque dignité, à chaque office, et à chaque état, soit civil, soit militaire, 4 vols. (Paris, 1786-1788), cited in Jean-François Labourdette, "Grands Officiers de la Couronne", in ed. Lucien Bély, Dictionnaire de l'ancien régime (Paris: Presses universitaires de France, 1996), 617.

${ }^{13}$ By the early modern period their number is usually (but not always) listed as eight: the Constable as head of the army; the Chancellor, head of the judiciary; the Household was run by the Grand Master, the Grand Chamberlain and the Grand Equerry. The remaining officers were also concerned with the military: the Grand Admiral, the Grand Master of the Artillery, and (collectively) the Marshals of France. Other posts with the word 'grand' that were sometimes included as Grand Officers included the Grand Almoner (head of the king's religious staff), and the Grand Veneur (Master of the Hunt). See Labourdette, "Grands Officiers de la Couronne".
} 
and regulated access to the king's private life from the earliest days of the Capetian monarchy. The clearest indication that this was a position of trust was the medieval tradition of the chamberlain sleeping at the foot of the bed of the king. He also was entrusted with the keys to the treasuries and other 'secret things' that were habitually kept inside the king's inner chamber. ${ }^{14}$ This was especially important in the more traditional layout of French palaces in the late middle ages - the celebrated openness of the French court was signalled by its twopart division between public hall and private chamber, unlike the more complicated divisions of the Burgundian and later Habsburg courts. ${ }^{15}$

In the middle ages, two posts, chambrier (cubicularius) and chambellan (camerarius) developed in tandem; the former was originally in charge of the monarch's private quarters, while the latter looked after the royal treasury and movable property. In time the chamberlain took over responsibilities for regulating access to these inner spaces. This post became dominated by princes of the blood from the fifteenth century, until the position was supressed by François I in $1545 .{ }^{16}$ The lesser post was held not by princes, but by magnates whose power base was local to the Ile de France, such as the Montmorency or Melun. ${ }^{17}$ From the early fifteenth century, the position of chamberlain rose in prominence and was awarded to royal favourites, notably Georges de la Trémoïlle and the Comte de Dunois. Dunois' descendants, the dukes of Longueville, held on to the position for a century-the first to be converted into a semi-hereditary post, perhaps justifiable as it was held by courtiers of royal blood (or at least semi-royal), and thereby strengthened the royal dynasty. ${ }^{18}$ This is in line with current thinking for the expansion of royal privileges to senior courtiers, notably via the creation of new, non-royal, duchy-peerages starting in the 1520s. Previously seen as simply a tool for weakening the political influence of the princes of the blood, I would argue instead

\footnotetext{
14 "He needed to be always near the person of the king, day and night, [...] and was guardian of the secret seals and of the caskets of the Cabinet." Anselme, Histoire Généalogique, VIII, 437.

${ }^{15}$ For an analysis of these differences, in the context of a 'neutral' court affected in part by both systems, see Jonathan Spangler, "Aulic Spaces Transplanted: the Design and Layout of a Franco-Burgundian Court in a Scottish Palace", The Court Historian, 14, 1 (2009), 49-62. For a more extensive analysis of the uses of space in French court structures, see also Monique Chatenet, La Cour de France au XVIe siècle: vie sociale et architecture (Paris: Picard, 2002). Or in Louis XIV's often-quoted words: 's'il y a quelque caractère singulier dans cette monarchie, c'est l'accès libre et facile des sujets au prince', Mémoires et Réflexions (1661-1715) (Paris: Communication et Tradition, 1997), 96.

${ }^{16}$ Summarised in Duindam, Vienna and Versailles, 28-29, citing published works by early modern jurists Jean $\mathrm{du}$ Tillet, Charles Loyseau, and an unpublished history of the office in series $\mathrm{O}^{1}$ ('Maison du Roi') in the Archives Nationales de France. The details that follow about the two posts are derived from Louis Moréri, Grand Dictionnaire Historique, vol. III (Basel, 1733): for the Grand Chambellan, pp. 13-14; for the Grand Ecuyer, pp. 648-649.

17 Three men named Jean de Melun, whose estates dominated the Seine valley above Paris, held the office continually for most of the fourteenth century. Anselme, Histoire Généalogique, V, 221ff.

${ }^{18}$ Dunois was an illegitimate son of Louis, Duc d'Orléans, brother of King Charles VI. His descendants struggled to define their status as full members of the royal dynasty for the next two centuries.
} 
that the creation of non-royal peerages was a necessary step taken to replenish dwindling numbers of royal peers - an integral part of ceremonial and representational aspects of the monarchy - as the various agnate branches of the royal house became extinct (through design or chance) in the late fifteenth century. ${ }^{19}$ The near total control over the principal offices of the household by ducs-et-pairs was an extension of this policy, and lasted until the end of the monarchy. The man standing behind the throne when the king was in his chamber, the Grand Chamberlain, was from this point onward always a duke and a peer of the realm.

But the office of Grand Chamberlain was also the first to be undercut by royal will, with the creation of the new post of Premier Gentleman of the Chamber, also in 1545, who took over much of the actual functions of the Grand Chamberlain (receiving oaths of chamber staff, signing their certificates of office, and managing relevant budgets). At first numerous, their number settled at four in the reign of Louis XIII (alternating by year), and can be seen quite clearly to have had the greater part of control of access to the Chambre du Roi, notably in informing the ushers and valets whom to admit, and in what order. A further limitation to the Grand Chamberlain's authority would come in the reign of Louis XIV, with the elevation of the office of Grand Master of the Wardrobe, "leaving the chamberlain with an undisputed but somewhat vacant supremacy". 20

Looking at the initial appointments of men to the posts of Premier Gentleman of the Chamber, especially in the reign of Henri III, we can see how the intimacy of the position of Chamberlain was replaced by that of Premier Gentleman. Henri filled these latter posts with favourites drawn from the lesser provincial nobility: Joyeuse, Epernon, Bellegarde. ${ }^{21}$ Still, the King was determined to ensure that the position of Grand Chamberlain, even so weakened, did not become hereditary in a grandee family, as indeed it had been in England for many centuries, where the Lord Chamberlainship was held by the De Vere earls of Oxford for

\footnotetext{
${ }^{19}$ Notably, the new peers were required to fill the six positions of the ancient lay peers at the royal coronation. Jackson, "Peers of France", 37. At the coronation of Louis XI in 1461, all six peers were princes of the blood. One-hundred years later, only one branch (Bourbon-Vendôme) survived. The six peerages in subsequent coronations were filled by mostly non-royal dukes, culminating in the coronation of Henri III (1575) where there were only two princes of the blood. The trend would be reversed entirely by the eighteenth century, however, and all six peers at the coronations of Louis XV and Louis XVI were once again princes of the blood. See the lists of coronation peers in the appendices of Cristophe Levantal, Ducs et Pairs et Duchés-Pairies Laïques à l'Epoque Moderne (1519-1790) (Paris: Maisonneuve et Larose, 1996).

${ }^{20}$ Duindam, Vienna and Versailles, 95 . Footnote 16 provides details of the on-going conflicts and contradictions in the sources concerning actual authority between the Grand Chamberlain, the Premier Gentleman of the Chamber, and the Grand Master of the Wardrobe.

${ }^{21}$ Nicolas Le Roux, La faveur du roi. Mignons et courtisans au temps des derniers Valois (Seyssel: Champ Vallon, 2001), chapter five ("La naissance de la majesté") discusses the role of the favourites of Henri III in developing the post of Premier Gentleman. All three 'mignons' came from the far south, Languedoc, Guyenne and Comminges, respectively; with the exception of the Joyeuse, their families had only limited contact with the royal court until the later sixteenth century.
} 
nearly five-hundred years. ${ }^{22}$ The Longueville family's hold on the office had already been lost in 1551, when the position was granted to another royal favourite, François de Lorraine, second Duc de Guise. ${ }^{23}$ Guise was a member of the King's extended kin group (through his mother, Antoinette de Bourbon), but he also held the household offices of Grand Master and Grand Veneur (Master of the Hunt), an indication of the extreme concentration of power in the hands of one family. The Guise family dominated the short reign of François II (married to their niece, Mary, Queen of Scots), and by the reign of Henri III, three Lorraine princes, the dukes of Guise, Mayenne and Aumale, held three of the eight Grand Offices of the Crown, and another, the Duc d'Elbeuf, was in position to succeed to a fourth, that of Grand Equerry, through his marriage to the daughter of the incumbent in $1583 .^{24}$ That a Grand Office of the Crown could be considered personal property to be inherited as part of a marriage portion demonstrates how far the late Valois had backed themselves into a corner in their efforts to counter-balance the princes of the blood by elevating non-royal magnates. In an effort to control this inflation of court honours, Henri III formally limited the number of Grand Officers of the Crown to six by ordinance in $1582 .{ }^{25}$ Nevertheless, the King clearly continued to feel hemmed in by the dominance of one family, and took extreme action in the double assassinations of the duc de Guise and his brother the Cardinal in December 1588.

The new Bourbon regime of Henri IV, however, regained control, and the King appointed men of his choosing to the Grand Offices of the Crown where he was able. He restored the post of Grand Chamberlain to the Duc de Longueville in 1589. He forced the young Duc de Guise to give up the charge of Grand Master in 1594, and awarded it instead to a Bourbon, the Comte de Soissons. Yet in the spirit of reconciliation for which his reign is known, Henri IV later returned the charge of Grand Chamberlain to a Guise, the Duc de

\footnotetext{
${ }^{22}$ G. E. Cokayne, et al., eds., The Complete Peerage of England, Scotland, Ireland, Great Britain and the United Kingdom, extant, extinct or dormant, $2^{\text {nd }}$ edn (13 vols, London: St. Catherine Press, 1910-1959), vol. X ("Oxford").

${ }^{23}$ Guise and Longueville contested the right to act as Grand Chambellan at the coronation of Charles IX in 1563. Elizabeth Brown, "'Franks, Burgundians and Aquitanians' and the Royal Coronation Ceremony in France", Transactions of the American Philosophical Society, 82, 7 (1992), 62, citing Théodore Godefroy, Le cérémonial de France, ou description des cérémonies, rangs et séances observées aux couronnemens, entrées et enterremens des roys et roynes de France (Paris, 1619), I, 316-19.

${ }^{24}$ While the marriage contract for Charles I, Duc d'Elbeuf, does not specify that Marguerite Chabot's dowry includes the office of Grand Equerry (Archives Nationales [AN], 273 AP 74, dossier Elbeuf), another reference to a document in the family's archives (AN, $\mathrm{T}^{*} 1559^{1}$, Cote 4, no 8, Act of Recognition, 1593) indicates that her father resigned his functions as Grand Equerry from the time of their wedding, and that Elbeuf had already taken 70,000 écus derived from the income from this position to cover his debts. Léonor Chabot, Comte de Charny, had also acquired his post by marriage to the heiress of the previous holder, Claude Gouffier, Duc de Roannais.

25 Labourdette, "Grands Officiers de la Couronne", 617: Constable, Chancellor, Grand Master, Grand Chamberlain, Admiral and the marshals of France. Henri III's earlier ordinances, however, indicated the Grand Equerry was also among these, and Henri IV definitively added that office to the list (1589), along with that of Grand Master of the Artillery (1605).
} 
Mayenne, after Longueville died in $1595 .{ }^{26}$ The post would remain in the hands of the Guise family for much of the seventeenth century, though actual authority in the Chamber continued to be exercised by the Premier Gentleman. The fourth Guisard, Elbeuf, did succeed his fatherin-law as Grand Equerry in 1597, but the King did not allow that office to pass to his son when he died suddenly in $1605 .^{27}$

The position of Grand Equerry (French écuyer, from Latin scutarius 'shield bearer'), had been a more menial royal officer in the middle ages, initially subordinate to the Constable who was in charge of the king's stables (as the Latin name, comes stabuli, indicates). But as the Constable took on more functions as commander of the royal armies, the Equerry took over most of his functions in the Maison du Roi. ${ }^{28} \mathrm{He}$ was given status as a 'Grand' officer (indicating that his oath was taken directly from the king, not from any superior officer) in the late fifteenth century. As with the first 'Grand' chamberlains, this was done to reward loyal service and friendship, notably in war. The first holders accompanied French kings on their campaigns in Italy: Pierre d'Urfé, companion of Charles VIII; and Claude Gouffier, childhood friend of François I, and son of that king's Grand Master and former governor, the Marquis de Boisy (who had himself been a successive favourite of both Charles VIII and Louis XII). ${ }^{29}$

Unlike the position of Grand Chamberlain, the Grand Equerry continued to rise in prominence and genuine authority, and remained a principal reward for royal intimacy, a clear demonstration of royal favour in public versus private spaces-recall that the Equerry's functions were mainly outside the royal palaces. Louis XIII elevated his favourites, first the Marquis de Cinq-Mars in 1639, then the Duc de Saint-Simon père (if you believe Saint-Simon fils), before it was 'stolen' by the Comte d'Harcourt, yet another Guise, in $1643{ }^{30}$ This choice

\footnotetext{
${ }^{26}$ Comte René de Bouillé du Chariol, Histoire des ducs de Guise (4 vols., Paris: Amyot, 1849-1850), IV, 329.

${ }^{27}$ Instead, Henry IV granted the office to his royal predecessor's earlier choice, the Duc de Bellegarde. It seems that after the royal coup of December 1588, when most of the Guise were imprisoned, Elbeuf's claim to his father-in-law's office was suspended (Chabot de Charny lived until 1597), and the office was exercised instead by Henri III's favourite, Bellegarde, until it was restored when the Guise made peace with Henri IV in 1594. Edouard de Barthélemy, Les grands écuyers et la grande écurie de France avant et depuis 1789 (Paris: Jules Bonaventure, 1868), 137, 158-59. That Elbeuf's son did not succeed can be explained by the fact that in 1605 he was only nine, and thus not capable of carrying out the duties of Grand Equerry (though see note 65, below, for contrast).

${ }^{28}$ Duindam, Vienna and Versailles, 30.

${ }^{29}$ Barthélemy, Les grands écuyers, 147-151; 155-157.

${ }^{30}$ The famous memoirist Saint-Simon's father was a favourite of Louis XIII, raised to the post of Premier Gentleman of the Chamber in 1628, and to the rank of duke in 1635, but was disgraced and banished until a deathbed reconciliation in 1643, during which the King - so says Saint-Simon-promised him the post of Grand Equerry. It was the Kings widow, the Regent Anne of Austria, who gave the post to Harcourt, supposedly after a supplication by his wife (significantly, a niece of Richelieu). Barthélemy, Les grands écuyers, 165-66. Louis de Rouvroy, duc de Saint-Simon, Mémoires, ed. Arthur de Boislisle (41 vols, Paris: Hachette, 1879-1928), I, 181188. Again on pp. 200-201, Saint-Simon rails against this 'crime' committed against his family.
} 
is in keeping with the theme of 'trust', as Harcourt was the only member of the House of Lorraine-Guise entirely trusted by the Bourbon regime in the $1630 s^{31}$

\section{Consolidation of Access}

At the start of the reign of Louis XIV, the House of Lorraine-Guise was therefore once again dominant in positions of at least ceremonial power, with both the Grand Chamberlain and the Grand Equerry accompanying the child king to a lit de justice at the Parlement of Paris, to his coronation in Reims, and during his official entrée into Paris in $1660 .{ }^{32}$ While the post of Grand Chamberlain soon passed into the hands of another grandee family, that of Grand Equerry would be held by a member of the House of Lorraine until the fall of the monarchy. Did these senior ceremonial courtiers regulate access to the sovereign? One of the defining marks of a royal favourite was his (or her) ability to control the distribution of patronage emanating from the sovereign, and much of this was done through the control of access to the sovereign's person. Louis XIV is known as the king without favourites (discounting mistresses for the moment ${ }^{33}$ ), but in the Comte d'Harcourt's son, Louis de Lorraine, Comte d'Armagnac, we can identify a combination of factors that point to him as one of the Sun King's few intimates: as Grand Equerry he attended the King on a daily basis when outside the palace, and as a prince étranger he had rights of access to most private spaces within the palace as well. ${ }^{34}$ Numerous examples can be found in contemporary memoirs in which 'M. le Grand' made use of his private time with the sovereign to act as a 'broker' on behalf of his clients, obtaining favours, offices, pensions. ${ }^{35}$ The clearest mark of his intimacy and favour was in securing a crucial element in the security of his family in the long-term at the French

\footnotetext{
31 David Parrott, Richelieu's Army: War, Government and Society in France, 1624-1642 (Cambridge: Cambridge University Press, 2001), 147. Much of the relationship established between Harcourt and Richelieu is discussed in my own book, The Society of Princes: The Lorraine-Guise and the Conservation of Power and Wealth in Seventeenth-Century France (Farnham: Ashgate, 2009), 74-75, 182-184.

${ }^{32}$ Henri Carré, L'enfance et la première jeunesse de Louis XIV (Paris: A. Michel, 1944), 62, 129, 143-146.

${ }^{33}$ Madame de Maintenon certainly must be recognised as the real arbiter of access in the later years of the reign of Louis XIV. Mark Bryant has clearly demonstrated how she became the portal through which ministers and courtiers sought the King in his twilight years. Mark Bryant, "Partner, matriarch and minister: Mme de Maintenon of France, clandestine consort, 1680-1715", in Clarissa Campbell Orr, ed., Queenship in Europe: The Role of the Consort (Cambridge: Cambridge University Press, 2004), 77-106.

${ }^{34}$ The princes étrangers, members of sovereign families from dynasties outside France, had rights of access by birth - not because of a position they held at court - to the most important ceremonial events of the king's day: lever, dîner, coucher. Men could remain covered before the king; women could be seated before the queen.

${ }^{35}$ Armagnac as a royal favourite is described in detail in chapter 3 of my book, The Society of Princes, "At Court: Lorraines and Royal Favour". Dangeau provides some excellent examples of his extraordinary favour: in 1689, Armagnac shielded a friend's son from the King's wrath after a disgrace; in 1713, he was received after the dîner in the King's cabinet (the King's most private space), where he was allowed to sit, and was accorded a favour he had requested concerning his daughter "in an instant". Philippe de Courcillon, marquis de Dangeau, Journal, eds E. Soulié, L. Dussieux, et al., (19 vols., Paris: Firmin Didot, 1854-60), II, 402; XIV, p. 318.
} 
court, one with a more general impact on the development of the Grand Offices of the Crown: an order of survivance, and a brevet de retenue. Letters of survivance ensured the succession of the post would be given to Armagnac's sons: one was given in 1677, then another in 1712 when the health of the elder son put the succession in jeopardy, and even included the grandson for good measure. ${ }^{36}$ A brevet de retenue (or d'assurance) assigned a cash value to the office, redeemable should the monarch wish to give the position to someone else. In 1717 (the year before Armagnac's death), this value was raised to one million livres, a mark of great favour by the Regent, the Duc d'Orléans. ${ }^{37}$ This was deemed excessive by Saint-Simon, who complained that it made the post hereditary, removing forever his chances (or those of almost any other courtier) from regaining a post he felt was rightfully his: "Until that point, I had patience; but this angered me." ${ }^{, 38}$ As with the offices of the French judiciary, this royal office had become venal, in practice if not in name.

The post of Grand Chamberlain was less easy to secure by one family, and its degree of control of access is more difficult to ascertain due to the strong influence of the Premier Gentleman of the Chamber. The Lorraine-Guise held it during the transition from Louis XIII to Louis XIV: firstly a second son, the Duc de Chevreuse, and after an intra-familial transaction of 1643, another second son, the Duc de Joyeuse. ${ }^{39}$ Joyeuse acted as Grand Chamberlain at the coronation of Louis XIV in June 1654, but died later that year; the King agreed to transfer the post to his older brother, Henri II, Duc de Guise. ${ }^{40}$ Financial problems led Guise to sell the post in 1658 to Godefroy-Maurice de la Tour d'Auvergne, Duc de Bouillon. ${ }^{41}$ The La Tour family had recently received full recognition of their status as princes étrangers, and a legal position as peers of France; they were eager to consolidate their position at court and in society further with one of the highest crown offices. ${ }^{42}$ Nevertheless, their hold on the office was not guaranteed: Louis XIV was frequently displeased with this

\footnotetext{
${ }^{36} \mathrm{AN}, \mathrm{O}^{1} 56$, fol. 60. Survivance for the Office of Grand Equerry had first been granted to Armagnac himself in 1651: AN, $\mathrm{O}^{1} 9$, fol. 382 .

${ }^{37}$ AN, O1 61, fol. 101. An earlier brevet d'assurance is mentioned for Armagnac, in 1649, but no value is given: AN, T 1503' ${ }^{1}$, Papers of the Comtesse de Brionne (unpaginated, listed in an inventory of 'Preuves de Noblesse Militaire des huit quartiers paternels' for Mlles de Lorraine who were applying for membership in the prestigious abbey of Remiremont in Lorraine).

38 “Jusque-là j'avois eu patience; mais cela me pique.", Saint-Simon, Mémoires, XXIX, 121.

${ }^{39}$ Resignation of Chevreuse to Joyeuse, 19 October 1643, and registration in Parlement of Paris, 27 August $1647, \mathrm{AN}, \mathrm{X}^{1 \mathrm{~A}} 8656$, fols $135-137$.

${ }^{40}$ Anselme, Histoire Génealogique, VIII, 456-457; AN, O${ }^{1}$, no. 10, fol. 91, 21 May 1655.

${ }^{41}$ The sale price is uncertain. A legal document from 1679 mentions claims made by the Duke's heirs that the figure of 400,000 livres had been omitted from his estate valuation in 1664 for the price of sale of the office. Bibliothèque Nationale [BN], Factum 14859.

${ }^{42}$ They had exchanged the sovereignty of Sedan for two duchy-peerages in 1651. Simon Hodson, "Princes Etrangers at the French Court in the Seventeenth Century: The Grimaldis, the La Tour d'Auvergne, and the La Trémoïlle", The Court Historian, III, 1 (1998), 24-28.
} 
family, retaining memories of the disloyalty of the Duc de Bouillon in the Fronde, and their status as princes would continue to be questioned, as a dynasty of less obviously sovereign origins (unlike the Lorraine-Guise, whose family had ruled the sovereign duchy of Lorraine since the eleventh century). ${ }^{43}$ A brevet de retenue would secure the highly prestigious and lucrative post at the top of the court hierarchy for succeeding generations.

The danger was revealed in 1684 when the King was offended too many times during his lever by the coarse manners of the Prince de Turenne (son of the Duc de Bouillon, filling in for him as survivancier of the office of Grand Chamberlain), and sent him away from court. ${ }^{44}$ This threatened the health of the entire dynasty, as a high court office was crucial for maintaining positions of intimacy and prestige with the king, crucial for the functioning of a successful aristocratic patronage network. ${ }^{45}$ The La Tour d'Auvergne were in this case fortunate in that, in addition to the office of Grand Chamberlain, they also held the office of Grand Almoner, the head of the King's ecclesiastical household. The Duke's brother, the Cardinal de Bouillon, Grand Almoner since 1671, therefore was able to use his intimacy with the King to attempt to smooth Louis' ruffled feathers regarding his young nephew. ${ }^{46}$ Subsequent comments made by the Cardinal demonstrate how important it was for this family to retain this post: he suggested that the Duke's eldest son should resign his survivance to his youngest brother (not the next in age), whose youth would ensure the position was held longest by a single individual. ${ }^{47}$ Later that year, the eldest son asked permission to serve abroad in Poland, and although the King agreed, he later recanted, and informed the Prince on his attempted return to court that he must leave the kingdom. ${ }^{48}$ In the end, the Prince de Turenne died before he could succeed, and his two younger brothers were both taken out of

\footnotetext{
${ }^{43}$ Even Saint-Simon conceded this point. Saint-Simon, "Sur les maisons de Lorraine, de Rohan et de La Tour", in Traités politiques et autres écrits, ed. Yves Coirault (Paris: Gallimard, 1996), 78.

${ }^{44}$ Dangeau noted in his journal the reprimand given by the King on 30 November 1684; Saint-Simon adds in his marginal notes that the young man had forgot to take off his gloves when handing the King his chemise at the lever, and the decorative fringes had hit the King in the face. Dangeau, Journal, I, 74-75.

${ }^{45}$ Sharon Kettering, "Brokerage at the Court of Louis XIV", The Historical Journal, 36 (1993), 69-87.

${ }^{46}$ Dangeau, Journal, I, 138. According to Hodson, however, the Cardinal was himself a frequent troublemaker, and it was his elder brother, the Duc de Bouillon, who maintained peace with the King. Simon Hodson, "Sovereigns as Subjects: The Princes of Sedan and Dukes of Bouillon in Early Modern France, c. 1450-1652" (DPhil dissertation, Oxford University, 1999), 389. A similar role can be seen performed by the Comte d'Armagnac as Grand Equerry, notably in his interventions to prevent the banishment of his son and his brother after a sex scandal in 1682. Spangler, Society of Princes, 110-111.

${ }^{47}$ Though the Cardinal insisted that ultimately the charge should return to the eldest son, so as not to diminish the grandeur of the head of the family. Letter of the Cardinal de Bouillon to the Duc de Bouillon, 19 November 1685, quoted in Horowski, "'Such a great advantage for my son"”, 165 (citing AN, 273 AP 188). It is worth noting also in this letter the Cardinal's clear intention that another son should be set aside with an ecclesiastical career in order to succeed him as Grand Almoner. Two Great Offices in one family are of course better than one, though this did not come to pass, and the Cardinal himself would lose the office in 1700.

${ }^{48}$ Dangeau, Journal, I, 138, 215-16.
} 
their ecclesiastical careers (one an abbot, the other a knight of Malta) before their father the Duke finally resigned his post as Grand Chamberlain in September 1715. The elder of these two sons, Emmanuel-Théodose, now Duc de Bouillon, then ensured another survivance was granted to his own son in 1717. The La Tour d'Auvergne did obtain brevets de retenue, but these were not as large - and thus not as unassailable - as those given to the Lorraine princes, only reaching 200,000 livres in 1743. Sometimes financial and dynastic health can get in the way of strategy, however, and by the 1770s, the Duc de Bouillon was in great debt and concerned that his son, though married, had no heir. In August 1775, he resigned the post of Grand Chamberlain in favour of his sister's son, Henri-Louis-Marie de Rohan, Prince de Guéméné, who deposited 800,000 livres to pay off liens placed by creditors on the Bouillon estate and to secure the brevet de retenue. ${ }^{49}$ But by 1782, it was Guéméné who was bankrupt - famously so, to the tune of thirty-three million - and another Rohan, the influential Comtesse de Marsan (former governess of the King) was forced to write to Louis XVI in 1788 demanding the survivance for the son of Guéméné. ${ }^{50}$ She was refused. In the last decade of the ancien régime monarchy, we therefore see the curious topsy-turvy situation where a Rohan performed the tasks of the Grand Chamberlain, while a La Tour d'Auvergne is listed formally as the survivancier. ${ }^{51}$

Thus the brevet de retenue is not the end of the story. Louis XIV, well known as a master of 'divide and rule', made sure to keep up the rivalries between the high officers of his household, notably between the Grand Chamberlain and the Premier Gentleman on the one hand, and between the Grand Equerry and the Premier Equerry on the other. We have seen that the Premier Gentleman of the Chamber had more actual duties in terms of regulating access to the Chambre du Roi. To a lesser extent the authority of the Grand Equerry was challenged by the Premier Equerry - a post originally conceived to manage the growing number of carriages needed to transport the monarch and his court (and the associated horses) within the department of the Grand Equerry.The independence of the Premier Equerry had grown, highlighted by the building of a separate Petite Ecurie as an architecturally symmetrical (that is, visually equal) structure to the Grande Ecurie at the new palace complex

\footnotetext{
${ }^{49}$ François Velde, "The Case of the Undying Debt", Financial History Review, 17, 2 (October 2010), 185-209, citing documents in the Minutier Central de Paris, at the Archives Nationales.

${ }^{50}$ Horowski, “'Such a great advantage for my son"”, 169, n. 119

${ }^{51}$ M. Poncelin de la Roche-Tilhac, Etat des Cours de l'Europe et des Provinces de France (Paris: Lamy, 1784), 63.
} 
of Versailles. ${ }^{52}$ Like 'M. le Grand', the Premier Equerry (his former subordinate, now his rival) was known by an extremely simple moniker in court language: 'M. le Premier'. The distinction remained purposefully vague — ever the Louisquatorzian method — and rival claims of the Grand Equerry and the Premier Equerry evolved into an open row following the death of Louis XIV in September 1715. ${ }^{53}$ In typical ancien régime fashion, decisions about precedence and rank were almost deliberately contradictory: a judgement of the Council of State, 22 October 1715, gave M. le Premier the spoils, 'entière \& totale', of the Petite Ecurie at the death of Louis XIV, and maintained M. le Grand in the rights, honours and preeminences which he had enjoyed under the late King in the Grande and Petite Ecuries; and equally the Premier Equerry in the Petite Ecurie was maintained in the independence from the Grande Ecurie which he had always enjoyed during the previous reign. ${ }^{54}$ In other words, no decision...

By this point, both of the 'lesser' titles had become more or less hereditary as well; the Premier Equerry being held by successive generations of the Beringhen family from 1645 to the suppression of the post in 1770, and the four posts of Premier Gentleman held by the same four families, who rotated on a yearly basis (and were all of ducal rank): d'Aumont, Rochechouart, La Trémoïlle, and Gesvres. ${ }^{55}$ As Leonhard Horowski has pointed out in his prosopographical study, the consolidation by the eighteenth century of the small number of families that dominated the top court offices is quantifiable, at around fifty. ${ }^{56}$ But we know that many of these posts were purely ceremonial - the clearest example being the position of Gentilhomme ordinaire de la chambre du roi given to Voltaire in 1744, hardly a position of trust to be exercised by a man frequently in exile for criticising the monarchy, despised by the King. ${ }^{57}$ Recently, research focus has also been applied to the day-to-day power-brokers, the real keepers of the keys of Louis XIV's bedchamber, the Premier Valets of the Chamber, as examined in great detail by Mathieu da Vinha. ${ }^{58}$ These were nominally within the department of the Grand Chamberlain, but appointed by the Premier Gentleman, though it is clear that the

\footnotetext{
${ }^{52}$ Dominique Massounie, "Les écuries de Versailles. Distribution et aménagement", in eds Roche and Reytier, Les écuries royales, 25-39; see also the previously cited Reytier, "Un service de la Maison du roi: les écuries de Versailles (1682-1789)", in the same collection.

${ }^{53}$ Saint-Simon writes extensively on this dispute: Mémoires, XXIX, 159-78, 183-84.

${ }^{54} \mathrm{AN}, \mathrm{O}^{1} 858$, no. 12.

${ }^{55}$ These four ducal families had secured these offices at various points of the reign of Louis XIV (Rochechouart being last, acquiring the post from the Beauvilliers in 1710). Only d'Aumont retained the office to the end of the ancien régime, but the others changed hands only once, to Richelieu, Duras and Fleury, respectively.

${ }^{56}$ Horowski, "'Such a great advantage for my son"”, see tables on pp. 159-161.

${ }^{57}$ Duindam, Vienna and Versailles, 92, fn. 8.

${ }^{58}$ Mathieu da Vinha, Les valets de chambre de Louis XIV (Paris: Perrin, 2004); and Alexandre Bontemps: Premier valet de chambre de Louis XIV (Paris: Perrin, 2011).
} 
former continued to benefit from their appointment financially. ${ }^{59}$ The Ushers (huissiers) of the Chamber have not been examined as rigorously, but can be demonstrated to have performed an even more crucial role in the day-to-day regulation of access and ceremonial, controlling who was admitted to the Chamber, and in what order (a highly visible mark of precedence and royal favour). ${ }^{60}$ But again, Duindam makes it clear that it was the Premier Gentleman who informed the ushers before each new quarter that they should not admit unknown persons to the king's chamber, and that no personal requests should be handed to the king by his chamber staff. ${ }^{61}$ Moreover, the Grand Equerry also had eyes and ears in the Chamber: his écuyers de la chambre had access to the monarch daily, as they inquired each morning at the lever whether the king planned to ride that day, and brought him his spurs. ${ }^{62}$ The Grand Equerry's staff also accompanied the king when he went to war, led chivalric ceremonies, and even provided his musical entertainment, both inside and out of the royal palaces. ${ }^{63}$

We must pause to recognise a duality in our original question: the true control of access had both public and private aspects. Publicly, that is ceremonially, access was regulated by the Great Officers of the Crown; whereas in private, the valets, ushers and equerries guarded the doors and the hunt. Where these overlap is in the appointment of the latter charges. And where true 'success' is concerned, from a dynastic perspective, we must return to the question of monopolies. While dynasties of valets came and went, ${ }^{64}$ the Grand Officers of the Crown of the eighteenth-century French court were now virtually fixed.

\footnotetext{
${ }^{59}$ Once again, as with the confusion noted above for the Ecuries, Da Vinha notes that while the Grand Chamberlain had lost the responsibility (or privilege) of nominating new valets and receiving their oaths of office to the Premier Gentleman by the reign of Louis XIV, sales of these offices still went into the hands of the Grand Chamberlain (known as 'parties casuelles'), so much so that Louis XVI had to fight to reclaim this lucrative source of revenue in his court reforms of 1780. Valets de chambre, 141-145.

${ }^{60}$ Tony Spawforth provides several clear examples gleaned from contemporary memoirs of the powerful influence of the ushers, sometimes to the detriment of the most powerful court families: Versailles: A Biography of a Palace (New York: St Martin's Press, 2008), 70-76.

${ }^{61}$ Duindam, Vienna and Versailles, 209, citing registers of the Premier Gentleman, AN, O1 822, pp. 12-13, 6063; and an Etat de la France (1687), pp. 202-203.

${ }^{62}$ Moréri, Grand Dictionnaire Historique, III, 648-649. Another member of the Grand Equerry's staff noted by Duindam (Vienna and Versailles, 235), was the porte-arquebuse, Sieur Antoine, who shared intimate time daily with Louis XIV when he fed and petted his dogs before going to sleep.

${ }^{63}$ These are listed in detail in successive published editions of the Etat de la France, for example, in 1692, chapter IV, "Grand Ecuyer", pp. 312-355, which specifies that the pages of the Grande Ecurie, along with those of the Petite Ecurie and the Chambre du Roy, served in the army as aides-de-camp to the aides-de-camp of the king, twelve from the Grande Ecurie and twelve from the Petite Ecurie, but in time of war shifting to twenty-four and twelve respectively. They held candles before the king when it was dark, accompanied him on the hunt, and carried his dogs to him on cushions (pp. 325-326). Ceremonial staff at the Grande Ecurie was headed by the 'Roy d'Armes', who coordinated his activities with about forty-five musicians divided between 'indoor' and 'outdoor' performers, depending on whether these were designated for military purposes, or at balls, ballets or comedies at the weekly appartement of the king.

${ }^{64}$ With the notable exception of the Bontemps family, who held the post of premier valet de chambre from 1643 to 1766 .
} 


\section{Monopolies of the Eighteenth Century}

By the eighteenth century, the houses of Lorraine-Guise and La Tour d'Auvergne-Bouillon were solidly in possession of two of the eight Great Offices of the Crown. ${ }^{65}$ As with nearly all of the highest court offices, these passed unhindered from generation to generation. ${ }^{66}$ And these were more than merely ceremonial posts: aside from the public prestige associated with a prominent place in the royal theatre of state, there were also very real profits to be made from selling posts within their departments - the Grand Equerry for example had about threehundred positions at his disposal - and through claims to royal property at the death of each monarch, in the chamber or in the stables. ${ }^{67}$ But we must return to the question: how did these two positions exercise actual power in the eighteenth century in terms of access to the sovereign?

First, there remained the basic factor of proximity. The Grand Chamberlain and the Grand Equerry rarely left Versailles without Louis XIV after the court was transferred there in 1682. As Grand Chamberlain, the Duc de Bouillon had a right to attend the King each morning at his lever, and to hand him his chemise unless outranked by a prince of the blood. As Grand Equerry, the Comte d'Armagnac attended the King whenever he went outside the palace on a hunt, which was often, or when he went to war. Both of these men were thus ideally placed at the centre of royal patronage from which point they managed their extensive clientele networks stretching outward to the provinces, both informally through long-standing personal links with the sovereign, and formally as provincial governors: Bouillon in

\footnotetext{
${ }^{65}$ Indeed, the security of the House of Lorraine is indicated by the willingness of Louis XV in 1761 to break the rules and permit a 'regency' for an underage Grand Equerry, his mother even being given the extraordinary title of 'Grande Ecuyère de France': “constituant une originalité incontestable dans l'histoire des grands officiers de la couronne". Reytier, "Un service de la Maison du roi: les écuries de Versailles", 64-68. Reytier stresses this was no empty title for the Comtesse de Brionne, demonstrated by numerous memoirs written by her concerning the administration of the Grande Ecurie, now in series $\mathrm{O}^{1}$ of the Archives Nationales.

${ }^{66}$ Of the eight Officers of the Crown listed by Henri III in 1581 (see note 13 above), the Constable was suppressed in 1626, the Chancellor remained strictly non-hereditary (as head of the judiciary), as did the various posts of marshal of France, while the offices of Grand Master, Grand Chamberlain and Grand Equerry were continuously held by the families of Bourbon-Condé, Lorraine-Guise and La Tour d'Auvergne. The reinstated position of Grand Admiral was held in the eighteenth century by the légitimé princes of Bourbon-Toulouse (or Penthièvre), and the Grand Master of the Artillery by the other légitimé line of Bourbon-Maine until it was suppressed in 1755. Amongst the other senior royal officers, the Grand Almoner was an ecclesiastical charge and could not easily become hereditary, yet was dominated by the House of Rohan for much of the century; the Grand Veneur was always a Bourbon-Toulouse; the Grand Master of the Wardrobe a La Rochefoucauld; and the Grand Provost a Du Bouchet de Sourches. Lesser known families held some of the junior offices for successive generations: Dauvet, Marquis Desmarets, as Grand Falconer; Sublet, Marquis d'Heudicourt, then Grossoles, Marquis de Flamarens, as Grand Louvetier (Wolf-hunter); and Dreux, Marquis de Brézé as Grand Master of Ceremonies. The champion for longevity was the House of Cossé (dukes of Brissac) who held the entirely ceremonial charge of Grand Panetier ('Bread Master') continuously from 1492 to the fall of the monarchy.

${ }^{67}$ See Spangler, Society of Princes, 106, for examples of the positions 'for sale' from the Grand Equerry. Upon the death of the king, M. le Grand had the right to claim for himself the horses of the royal stables and of the stud farm, the equipment, and all the movable furnishings kept there.
} 
Auvergne, Armagnac in Anjou. As with their Grand Offices of the Crown, both of these governorships became unofficially hereditary in these two families during the reign of Louis XIV. But neither governor was resident in his province. Instead, his constant position at the side of the King meant that notes could be put into his pocket, or words spoken into his ear, obtaining pensions, court offices, military commissions, and ecclesiastical posts for hundreds of clients. ${ }^{68}$ At a higher political level, the Grand Equerry, as a prince of the House of Lorraine, also enjoyed the privilege of escorting foreign ambassadors to their audience with the sovereign; whereas in the Chamber, these important visitors were guests of the Grand Chamberlain. ${ }^{69}$ We can only speculate on the level of impact these moments of private interaction had on foreign policy in the eighteenth century.

There is one further perquisite that sets these two positions apart from the other Grand Offices of the Crown and allows us to consider their real impact on royal access: both were involved with the recruitment of the two groups of royal pages, those of the Chamber and those (much larger) of the Stables. This was a key position for regulating access for nobles who were not from traditional court families, or perhaps were from younger branches of court families who resided in the provinces. ${ }^{70}$ The central feature of any nobleman's selfconceptualisation was a military career, as seen by those of the robe nobility so keen to use military service to promote their families into the ranks of the sword nobility in the eighteenth century. The best way to get started in this career was as a page in the Grande Ecurie. ${ }^{71}$ Each page was vetted before he was admitted for his noble ancestry-his noble status had to predate 1400 - by the royal genealogist. Significantly, the post of royal genealogist (held by several generations of the d'Hozier family) fell under the jurisdiction of the Grand Equerry. ${ }^{72}$

\footnotetext{
${ }^{68}$ Again, for the Comte d'Armagnac, see examples of clientage in his capacity as governor of Anjou in Spangler, Society of Princes, 108-109. For the ability of absentee royal governors to effectively control patronage in their provinces, see Beth Nachison, "Absentee Government and Provincial Governors in Early Modern France: the Princes of Condé and Burgundy, 1660-1720”, French Historical Studies, 21, 2 (Spring 1998), 265-297.

${ }^{69}$ Charles-Philippe d'Albert, Duc de Luynes, Mémoires du duc de Luynes sur la cour de Louis XV (1735-1758), eds L. Dussieux and E. Soulié, (17 vols, Paris: Firmin Didot, 1860-65), V, 138.

${ }^{70}$ This was demonstrated in an early example of prosopographical analysis by François Bluche, "Les Pages de la Grande Ecurie", Les Cahiers nobles, 28-30 (1966). More recently, see the wider study on household officers by Sophie de Laverny, Les domestiques commensaux du roi de France au XVIIème siècle (Paris: Presses de l'université de Paris-Sorbonne, 2002). Examining a list of the pages at the Grande Ecurie in 1692, for example, one can see several names of major court dynasties such as La Tour, Durfort, Harcourt, Simiane, Grimaldi, but qualified by additional names indicating membership in junior branches. Etat de la France (1692), pp. 322-325. This can be seen more widely in lists of pages published at the end of Barthélemy, Les grands écuyers et la grande écurie.

${ }^{71}$ Ellery Schalk, "Pluvinel, le renouvellement de la noblesse et les prémices de l'École de Versailles", in eds Roche and Reytier, Les écuries royales, 169-175. See also Jay M. Smith, The Culture of Merit: Nobility, Royal Service, and the Making of Absolute Monarchy in France, 1600-1789 (Ann Arbor: University of Michigan Press, 1996).

${ }^{72}$ For four generations of d'Hoziers, see Alain de Grolée-Virville, Les d'Hozier: juges d'armes de France (Paris: Éditions cardinales, 1978).
} 
It is a safe assumption that a nod from M. le Grand could give an aspiring country gentleman an advantage in the approval of his family's genealogical claims by the généalogiste $d u$ roi.The school for the pages, housed in the Grande Ecurie, was where young nobles learned the skills for life as a courtier: they learned equitation and ballet, manners, and how to be a soldier. Successive kings too learned to ride here and, it should be stressed, socialised with other young nobles. ${ }^{73}$ As has been noted, the Grand Equerry accompanied the monarch on military excursions, and therefore the pages that he chose as part of his suite were given an undeniable opportunity for close proximity to the monarch himself, something hopefully remembered when the young nobleman was later seeking a position at court or a military command.

The number of nobles educated in this manner reached about 150 in the eighteenth century, and they were placed throughout the court, in the king's chambers, but also in the households of the queen, the dauphin, other royal children, and the princes of the blood. They served three to four years, then typically joined one of the court's elite military units. ${ }^{74}$ Félix d'Hézecques left behind memoirs of his life as a page in the reign of Louis XVI, and demonstrated the regular access they had to the sovereign through accompanying him on the hunt, or performing ceremonial tasks in the Chamber. ${ }^{75}$ One specific instance of control was the practice that developed in the eighteenth century of the 'hunt supper', which only 'presented nobles' could attend, regulated by the pages and equerries assigned to serve the king on these outings. ${ }^{76}$ We know from records in the Archives Nationales, series $\mathrm{O}^{1}$, that the successive Grand Equerries of the House of Lorraine were active managers of this vast enterprise, maintaining a large apartment on the top floor of the Grande Ecurie itself, and personally overseeing details from financial administration of the stables to the purchase of horses for the king's use. Hézecques describes the last Grand Equerry, the Prince de Lambesc (Charles-Eugène de Lorraine), as very 'hands on': up every day at five ('even in winter') at the riding school, mounting or dressing horses or giving riding lessons. ${ }^{77}$ The Grand Equerry

\footnotetext{
${ }^{73}$ In the late eighteenth century there were 162 pages at the riding schools: 88 from the Ecuries (48 Grande and 40 Petite), and 74 from other services (6 from the Chamber, 12 in the Queen's service, and the rest in the service of the King's brothers and sisters). Other écoliers included members of the royal family itself: in 1761, the Duc de Chartres and the Prince de Lamballe. Royal riding pupils included Louis XIV taught by Arnolfini, his son the Grand Dauphin by Duplessis, and both younger brothers of Louis XVI by Neuilly. Reytier, "Un service de la Maison du roi: les écuries de Versailles", 83-84.

${ }^{74}$ Duindam, Vienna and Versailles, 57.

${ }^{75}$ Hézecques details how pages were present at the grand lever, accompanied the king to mass, collected game on the hunt, and handed the king his slippers at the coucher. They also held trains for princesses, rode on horseback behind their carriages, and so on. Souvenirs d'un page de la cour de Louis XVI, 113-114, 117.

${ }^{76}$ Spawforth, Versailles, 135. See Philippe Salvadori, La Chasse sous l'Ancien Régime (Paris: Fayard, 1996).

${ }^{77}$ Hézecques, Souvenirs d'un page, 122.
} 
was not just in charge of the school for young nobles at Versailles, he also had authority to oversee all equitation academies across France, plus the royal stud farms, and even the posts and relay services. ${ }^{78}$ His network would have formed the very backbone of the provincial noblesse seconde in their attempts to connect with the court in the eighteenth century. As recently put by Christophe Blanquie regarding household service more generally: "The royal household offers among other things a refuge at the court for the minor nobility who otherwise would have no access to it.",79

In parallel, the level of control the Grand Chamberlain had in the daily running of the Chamber, or more specifically in the nomination of pages or ushers, and over their subsequent careers, requires further research. Just as the Grand Equerry's genealogist exercised significant authority in admitting noble sons to the school for pages, can we identify a parallel position or body overseen by the Grand Chamberlain for 'indoor' spaces of the monarchy? Did he retain any of the regulatory powers of other European court chamberlains, most notably the Imperial Grand Chamberlain (Oberstkämmereramt), to determine who could or could not be admitted, for example, to the honneurs de la cour $?^{80}$ We can say that the erosion of the real patronage power exercised by the Grand Chamberlain beyond the immediate world of the court had been severely curtailed by the eighteenth century when compared to that of the Grand Equerry. Formerly the Grand Chamberlain had exercised jurisdiction over industries that supplied personal goods to the monarch and his court, notably the garment industry in Paris, but from the 1660s this privilege was exercised by the Grand Master of the Wardrobe. ${ }^{81}$ Similarly, the Premier Gentleman of the Chamber had not only taken over the task of receiving the oaths of the officers of the bedchamber and regulating expenses, he also took over the function of organising state funeral ceremonies and overseeing the king's entertainments, including (after 1757) the two main theatre companies in Paris, the Comédie française and the Comédie italienne. ${ }^{82}$ Yet a complete dismissal of the office of Grand Chamberlain as merely honorific is premature: according to the 1722 Etat de la France, in addition to ceremonial duties-notably overseeing homage rites and ceremonies for the

\footnotetext{
${ }^{78}$ Spangler, Society of Princes, 106-107, citing letters patent from AN, series $\mathrm{O}^{1}$.

79 "La maison du roi offre d'ailleurs un refuge à la cour à une petite noblesse qui n'y aurait plus accès autrement", Blanquie, "Dans la main du Grand maître. Les offices de la maison du roi", 272.

${ }^{80}$ This is discussed in context of French émigrés in Vienna during the Revolutionary era by William Godsey, “"La société était au fond légitimiste': Émigrés, Aristocracy, and the Court at Vienna, 1789-1848”, European History Quarterly, 35 (2005), 63-95.

${ }^{81}$ Etat de la France (1722), I, 286.

${ }^{82}$ Nicolas Viton de Saint-Allais, Dictionnaire encyclopédique de la noblesse de France (2 vols, Paris: Valade, 1816), II, 54-55.
} 
conferral of knighthoods - he maintained a position at the king's side daily, entrusted with the king's privy purse "for his day-to-day expenses". 83

\section{Conclusion}

Intimacy and trust remained primary defining features of the Grand Offices of the Crown. These were men the king grew up with, socialised with, and felt most comfortable with due to their high rank. As is now widely recognised by French historians, the high court nobility were not prisoners in a 'gilded cage'; rather they benefitted from the increased centralisation of the 'co-operative' monarchy. But was this a positive development for the health of the French monarchy? Was it healthy for the provincial nobility who became ever more focused on careers and largesse at Versailles to the detriment of their centuries-old links within their home regions and local estates? In the absence of a minister-favourite (after Fleury), someone who could bridge the gap between court and government, was the monarch cut off from reality, surrounded only by noblemen who had been screened by the departments and officers of the Grand Chamberlain or the Grand Equerry? From the point of view of the monarchy, this was not a healthy development. For the court aristocracy, however, dynastic health meant long-term stability in their access to royal largesse and the ability to distribute material and honorific graces to family, friends and clients. In this way the Grand Officers of the Crown remained the most powerful men in France in the ancien régime. This was achieved largely through their control of access to the court as a whole, not specifically to an individual monarch.

In the final review, we must conclude that there are both similarities and differences in the 'keys' that were held by the Grand Chamberlain and the Grand Equerry of France, and in the doors they opened. Both offices retained the social prestige incumbent in one of the central 'performative' positions in French royal ceremonial life, and a good deal of the revenues accrued through gradual assumption of the monarch's powers of patronage within his own household. Both had obtained the crucial ingredient for the success of any court dynasty: close proximity to the monarch on a daily basis. The Grand Equerry retained more of a clearly identifiable source of regulatory power, both in his role as master of the hundreds of pages that served the court, and overseer of the schools where they learned to be courtiers. To

\footnotetext{
${ }^{83}$ Etat de la France (1722), I, 287-88. Nevertheless, the contestations between the roles of the Grand Chamberlain and the Premier Gentleman were so clearly unresolved as late as 1722, that the author of this edition of the Etat printed a 'warning' at the start of the volume proclaiming his innocence specifically about these two offices in case any discrepancy printed within might spark a formal challenge.
} 
complete the comparison, however, further detailed research is required to identify the day-today regulatory functions of the Grand Chamberlain, if any. ${ }^{84}$

Any court history is replete with details about successful individuals who exercise control over access, notably favourites like Henri III's mignons, or Madame de Maintenon in the Sun King's dotage. We might therefore make comparisons with Louis XIV's Grand Equerry, Armagnac: was his power at court and his intimacy with the King due to the office he held, his inherited rank of prince étranger, or simply his character as an individual? $\mathrm{He}$ was clearly someone Louis had known all his life and felt comfortable around. The King trusted him. The same cannot be said unquestionably about Louis XIV's Grand Chamberlain, Bouillon. But the true mark of Armagnac's trust was that this intimacy was extended institutionally to his descendants for the rest of the ancien régime, and even beyond. ${ }^{85}$ And that, personal feelings aside, this most 'absolutist' of French kings did not remove the office of Grand Chamberlain from Bouillon or his descendants. The power of favourites like Maintenon or Armagnac was certainly connected to individual qualities, but from the point of view of thehistory of the court of France in its last century in general, this power is less relevant than the long-term maintenance of regulatory control of patronage by courtly dynasties, generation to generation, a monopoly of access.

\footnotetext{
${ }^{84}$ Reference should be given to the recent publications of Pauline Lemaigre-Gaffier, whose work on the MenusPlaisirs of the royal household in the mid-eighteenth century indicates that much of the regulation of the activities and finances of the Chambre du Roi was indeed done by the Premier Gentleman, not the Grand Chamberlain. See notably her recent monograph: Administrer les Menus Plaisirs du Roi. La cour, l'État et les spectacles dans la France des Lumières (Ceyzérieu: Champ Vallon, 2016); and "Des oeuvres d'art aux pratiques documentaires: les Menus Plaisirs et l'invention d'une mémoire administrative au XVIIIe siècle', eds Pierre Jugie and Jérôme de La Gorce, Les Menus Plaisirs du Roi. XVIIe-XVIIIe siècles (Paris: Presses de l'université de Paris-Sorbonne, 2013), 11-27.

${ }^{85}$ The Prince de Lambesc, last Grand Equerry of the ancien régime (and some say partly responsible for its fall), did not return to France after the Restoration of 1815. He did continue to hold the title of Grand Equerry under Louis XVIII, but the actual duties were carried out by junior officers. Barthélemy, Les grands écuyers et la grande écurie, 140.
} 